\title{
Islam and the Creative Imagination in Senegal*
}

\author{
Mbye B. Cham**
}

In few other places ${ }^{1}$ in the creative traditions of sub-Saharan Africa is the factor of Islam more prominent and influential than in Senegal. Manifested on the level of form and subject-matter and spanning a wide cross-section of talent in both the traditional and modern media of creative expression, this prominence and influence can be attributed to a number of factors ranging from the artistic maturity, religious sensibility, intellectual astuteness and ideological orientation of individual artists to the more general impact that Islam, as a dominant religious force, is perceived to have had on secular life in Senegal. These factors, to a large extent, determine the various ways in which individual Senegalese artists define themselves and their art vis-a-vis Islam, in particular, and society, in general, definitions which creatively translate into formal choice, thematic focus ${ }^{2}$ and, to use a cliche, "message".

Two opposite sets of equally militant attitudes constitute the polar extremes that bracket the range of Senegalese artists' creative response to Islam, thus paralleling or 'reflecting' similar patterns that obtain in the society at large. This is hardly surprising, given the conception that Senegalese, and indeed, most African artists, have of the nature and function of art in society. On one pole is that ensemble of attitudes shaped by a zealous embrace and vigorous advocacy of the primordiality of Islam as the most, indeed, the only, legitimate and effective vehicle for the totalization of the individual and the society. Art in the hands of individuals on this end of the creative spectrum becomes an instrument of propagation of religious ideals, in this case Islamic religious ideals. But beyond this religious vision or in conjunction with it, cultural and

*This paper was presented at the conference on "Popular Islam in Twentieth Century Africa" at the University of Illinois, Urbana-Champaign, April 2-3, 1984.

***Mbye B. Cham, Ph.D., is an Assistant Professor of African Literature and Film at Howard University. Washington, D.C.

${ }^{1} \mathrm{Cf}$. Northern Nigeria among the Hausa and the Fulani, and Northern Sudan.

${ }^{2}$ For more detailed discussion of the influence of religious sensibility on literary techniques and theme, see Johnson, 1980, and Amar Samb, 1968, 1972. 
artistic canons of the language of Islam, i.e. Arabic, are appropriated wholesale or adapted in the name of authenticity and put to the service of secular ideals with roots deep in the religious ethic. Total assimilation, to use Fanon's terms, constitutes the most pronounced trait of this category of creative enterprise undertaken by Senegalese Muslim clerics and griots writing and performing in Arabic, Wolof and Peul. Poetry, both oral and written, is the privileged genre here, and among the more celebrated practitioners figure El-Hadji Abdoul Aziz Sy, ElHadji Ibrahima Niasse, Moussa Ka, El-Hadji Ahmadou Bamba Mbacke, Khali Madiakhate Kala (see Diop, n.d.: pp. 66-70 and Samb, 1968, 1971, 1972).

Moving left, a nudge away from this first category, is another group of artist believers, different from the first group only in language and form of expression. Instead of Arabic and the indigenous languages, French becomes the principal medium utilized, and the novel replaces poetry as the vehicle for setting up Islam as the most secure shield against Western individualist/materialist decadence, as exemplified in Cheikh Hamidou Kane's L'Aventure Ambigue (Ambiguous Adventure), and as the most solid foundation on which to predicate the human and moral development of Senegal, as conveyed in Aminata Sow Fall's La Grève des Battù (The Beggars' Strike).

The central point on the spectrum of creative responses to Islam in Senegal is occupied by works belonging to that sphere of creativity generally referred to as oral traditions. These represent creations in the indigenous languages and forms as well as translations and recreations of these into French. The series of renditions in French of the narratives of Amadou Koumba by Birago Diop $(1958,1961,1963)$ stands out in the latter category. Their median position on the spectrum is a function of a somewhat ambivalent response to Islam, characterized by a constant alternation between reverence and mockery. In the oral traditions, the pietistic zeal and aura of the first two groups are tempered by an attitude of mild irreverence which reveals and pokes fun (in ways that may appear sacrilegious to the devoutly religious) at the humanness of that most pious earthly symbol of Islam, the Serigne/Marabout. Yet, this attitude goes no further, that is, belief in the ideals of Islam still regulates behavior and life.

It is only among the next two groups of artists toward the left end of the spectrum that the mild irreverent attitude of the oral traditions begins to acquire radical traits which in their extreme, border on apostasy. Professing different degrees of belief or disbelief, and working in fiction in French and cinema in the indigenous Senegalese languages, these artists utilize forms (and in some cases, language) whose origin is essentially non-African to expose and contest what they regard as religious distortion, particularly, the crafty exploitation of Islam at all levels of society as a mask to hide self-centered secular interests of the kind that are inimical to the creation of conditions likely to foster the 
totalization of individual and society.

One group represented by the work of Mahama Johnson-Traore (1972, Njangaan) and A. Samb (1973, Matraque Par Le Destin ou la Vie D'un Taalibe), is located at a point midway between the central point occupied by oral traditions and the left extreme bracket of the spectrum occupied by the work of Ousmane Sembene. Characteristic of this group is the way it graphically exposes and vehemently denounces the misuse of Islamic institutions and principles, in this case educational, and the exploitation of the religious faith of the masses by Serigne/Marabout, big and small. What distinguishes this set of attitudes from that encountered in the oral traditions is the contempt for the Serigne/Marabout, portrayed as ruthless and exploitative, whose actions are related to wider social and political issues. However, inspite of this assault on Qur'anic education as practiced in Senegal, Traore, in particular, professes faith in Islam ("Je suis musulman et croyant"*, he kept reminding audiences after screenings of Njangaan during a Crossroads-sponsored tour of the U.S. in October 1983), and, implicitly, its place in Senegalese society.

Ousmane Sembene, on the other hand, represents the left extreme of the spectrum. His artistic response to Islam in Senegal is as unequivocal as that of the marabouts and clerics at the right extreme of the spectrum. In sharp contrast to this group, however, Sembene marshalls the full range of his creative potential to embark upon what has become the most irreverent scrutiny of Islam (indeed, all religions) in all of its manifestations, a scrutiny unprecedented and unequalled in Senegalese and African creative expression in its studied system, severity and frequency. Embracing an ideology that is fundamentally materialist, Sembene combines satire, irony and naked frontal attacks to convey an essentially iconoclastic view of Islam which he portrays as colonial in nature and, therefore, an impediment to secular individual and social fulfillment in Senegal.

Thus, the major portion of Senegalese literature and film, differentially engages Islam in its totality. However the critical literature on this tradition has thus far failed to explore the nature and the breadth of this 'engagement' which, all too often is overshadowed by attention to the Euro-Christian colonial factor. Scholarly fixation on Cheikh Hamidou Kane's L'Aventure Ambigue (Ambiguous Adventure) as the only creative work to have engaged Islam also betrays ignorance of literary history and the very nature of literature itself in Senegal. The notion of a spectrum of creativity advanced here provides the best framework for examination and understanding of the persistence of Islam and its impact on secular thought and action as the most enduring and pronounced theme cluster transcending genre and linguistic boundaries in Senegalese creative practice. It is to this spectrum that we now turn our attention to detail the nuances of the various types of artistic responses to Islam. 


\section{THE BANU SA'D OR THE PROMOTERS}

Although Islam arrived in Senegal as early as the eleventh century (Samb, 1968: p. 629), it was only with the conversion of the Damel of Cayor, Lat Dior Diop, in the latter half of the eighteenth century that the bulk of the Wolof converted to the new religion. In the wake of the advent of Islam and with the development of religious education, there arose an indigenous elite versed in the teachings of the Qur'an and literate in the Arabic language and culture, skills which were to constitute an important part of their efforts of proselytization and establishment of relatively independent centers of religious and secular power. ${ }^{3}$ From this etlite came also the pioneers of creative writing in both Arabic and Wolof (the latter system referred to as 'Wolofal' that is, writing in Wolof using the Ajami script). This phenomenon continues to this day, coexisting with other forms of creative expression, both oral, literary and cinematic.

Because of the near total absence of distinction between Islam and the Arabic language, ${ }^{4}$ literary expression in Arabic and Wolofal among Senegalese Muslim clerics and scholars becomes a religious undertaking, hence the preponderance of themes clustering around Islamic hagiography, religious virtue and duty, and the dependence on formal and technical norms and conventions culled primarily from the Qur'an and Arabic creative traditions. Amar Samb's study on this aspect of literary creativity among the Wolof Muslims is invaluable, and this section of our essay owes much to his findings. The formal and thematic dependence of part of Wolof literary creativity on Islañ is succinctly captured by Samb when he makes the following observation:

What does "Wolof" poetry owe to the Muslim religion? Primarily the metre, the frame and the technique of the grand quasida or ode. All the classical themes explored by Arab poets are developed by those [Wolof poets/clerics] referred to earlier [i.e. Moussa Ka, El-Hadji Abdoul Aziz Sy, etc.](Samb, 1968: p. 634).

Although one may take exception with Samb's attribution of the ode to Arabic sources-does not the Wolof have the tagg or praise poem/song which is preIslamic-details of this dual allegiance leap to the surface when one takes a look at a representtive sample of works created in this tradition. In evidence are not only panegyric to the Prophet Muhammad, religious masters, history of the prophets and expositions on Islamic eschatology, but also an impressive array of Arabic metrical patterns-

${ }^{3} \mathrm{Cf}$. For a detailed account of these, see Behrman, 1970 and Cruise-O'Brien, 1971 and 1975. ${ }^{4}$ Manadou Dia's remarks: "Islam is not only a religious doctrine, it is also a system of thought, a culture and an institution," and "Islam is first and foremost a philosophy, a culture which owes a lot to the Arabic language, the language of the Coran." All translations from the French are mine, unless otherwise indicated. 
tasmit, mutaqarib, basiit, madiid, rajaz, etc.-and poetic formulae.

It is hardly surprising, then, to see a praise poem by El-Hadji Abdoul Aziz Sy composed in Arabic and Wolof, as can be seen in the following extracts from the poem dedicated to his elder brother, Abu Bakr Sy, the first Calife of the Tijani brotherhood at Tivavoune:

Hamdan lirabbin Kariimin Khassanaa Tyilubir

Tyiây ngoneelammitakh may dyog difentati woy

Abaal-Habiibi wa rabbi-l-ardi

Yaa dyara woy

3

Khaliifatu sheikho wa-l mukhtaaru

Yaa fi di mbör

Yaa fii fêgal diina ay daanam

Te nyepp lowar

Tyoos lên! te bakako

Bil - Amdaahi mooko yayoo

Daan sadyo gaangi

Te tosbit moodi

Mbor - mi ko-dyar

Minal - basiiti, maddidin

Kaamilin, ramalin,

Wa waafirin, rajazin,

Banye - de tamaak sabar (Samb, 1969: pp. 636-7).

Translation:

Glory to the Generous Master who has no doubt authorized me To get up and compose a song in praise of his merits

O Father of Habib, O Lord of the earth!

It is you who is most worthy of praise.

3

O Calife, O Master, 0 the chosen one!

It is you who is the champion here

It is you who protects the religious against the evil of its enemies

Even though this is our duty all!

Move, exhalt him with praises

They are his due

Here is the invincible champion!

Lift up a leg to exhalt him

He who is the champion 
(Praise him) in basiit, madiid,

Kaamil, ramal

Waafir and rajaz

Instead of using tama and sabar

The interlinear use of Arabic and Wolof (line 1 in stanzas 1 and 3 and lines 1, 2 and 3 in stanza 6 are in Arabic, and most of the rest in Wolof) is a procedure typical of this creative tradition in Senegal, and may in some way, be expressive of a similar process within the larger context of the contact between Islam and Senegal. Ironically, though, the poet seems unbothered or unaware of the contradiction, evident in stanza 6 , in his advocacy for the use of Islamic/Arabic metre and poetic convention over supposedly 'pagan'/un-Arabic tama and sabar while much of the language of the poem-Wolof-belongs to the same cultural universe as the tama and sabar.

Moussa $\mathrm{Ka}$, the celebrated Wolof poet and disciple of Ahmadou Bamba, the former Calife-General of the Muriddiyya brotherhood, whose poetic creations in Arabic he translated in Wolof, also makes creative use of Arabic-such as "Faa'ilun mafaa'ilatun"-to cast the rhythmic patterns of his compositions many of which carry the end rhyme "Ya-Allahi"(Samb, 1968: p. 634). Just like his mentor and peers, he uses his imaginative and creative skills to propagate the word of Allah while at the same time employing the praise mode to exhalt the glory and saintliness of revered individuals, such as Ahmadou Bamba, and their devotion to the ideals of the religion. His diwan (oeuvre) entitled Barzakh (Samb, 1968: p. 634), together with that of his master, Ahmadou Bamba, forms a significant part of the ensemble of the poetic repetoire of the Muriddiyya, in particular, and the other Islamic brotherhoods, in general, a repetoire characterized by a "religious current" and "a sense of the marvellous inspired by the mystique of saintliness." (Diop, B.M. n.d.: p. 106). These elements are quite pronounced in Moussa Ka's poem "Ma dyema burati..." (Ka, 1968) ("I'll try to uplift myself again...").

Written much earlier but translated and published only in 1968 and too long to reproduce here, "Ma dyema burati..." stands out as one of the poetic masterpieces in Wolof, remarkable not only for its refined religiosity and erudition but also for its fine artistry. In eighty lines of classical Wolof, each of which ends with a trill rhyme, Moussa Ka makes skillful use of Islamic hagiography and the device of repetition to effectively convey some of the more salient aspects of Islamic eschatology. An ode to humility, piety and devotion, the poem recreates the history of many saints of Islam, as conveyed in the Qur'an, as a mechanism for underscoring the ephemeral nature and mortality of

${ }^{5}$ Tama and Sabar are two kinds of Wolof drums. The translation of the poem is mine, and it is based on Samb's French translation of the original. 
human existence. The death of the Prophet Muhammad is held up to be the prime confirmation of this fact:

Ndegam ka takh Yalla bindoon moo ming ne mes Andaak Sahaaba ya, mbôôlôô moo fi gis dana far (p. 848)

Since He (i.e., Muhammed), in whose honor God created, is no longer here,

As well as His companions, everyone you see here, will also go.

The poem continues along these lines, alluding to the glory and feats of saints like Sulayman ("...ki moomoon dend bepa..., Daan war ngelaw..." "Who was Master of all the universe..., who used to ride the wind..."), Ayooba ("Yonent ba daan muyn ba fatte diabar"; "the prophet whose enduring patience and self-denial made him overlook a wife") and Issaa Ibn Maryama ("Di soopi yeforya mbaamal-la, bunyu ko moyaan" “...the one who transformed disbelievers into swine, because they refused to follow his way") who also died inspite of their virtues and greatness. Much of the poem also expounds on concepts of heaven and hell and the pre-conditions for entering one or the other. The thrust of the principal message of this poem? The need for a clean pious life in order to avoid the hot fires of Diahanama (Hell) and gain access to Tuuba and Firdawsi (two places in Paradise) under the guidance and protection of Serigne Touba (Ahmadou Bamba M'Backe). [See lines 77-80 of the poem.]

Space does not allow a more detailed analysis of this poem and of the works of other celebrated Wolof poets, such as El-Hadji Ibrahima Niasse and his daughter Rokhaya Niasse of the Kaolack School ${ }^{6}$, who see their creative activity as an extension of their devotion to Islam even when their work is based on the current secular reality. Their conception of Islam as an indigenous integral part of the Senegalese socio-cultural and religious patrimony and as the only effective guide for meaningful individual and social thought and action has made its imprint on many levels on their artistic products. Islam, for these individuals, is supreme. A similar disposition is echoed, albeit in modified form, in the creative work of the next group of artists on the spectrum.

Products of the African, Arab-Islamic and Euro-Christian education, Chiekh Hamidou Kane and Aminata Sow-Fall have had to come to terms with the conflicting values and orientation of these systems which structure and regulate their reality. Their efforts to imaginatively synthesize or resolve these conflicts have invariably resulted in a wholesale embrace of the African and the Islamic, integrated into one indivisible whole in the case of Kane, especially, and a rejection of the Western Euro-Christian, portrayed as a powerful intruder, the harbinger of destabilization and death in all senses of the word.

${ }^{6}$ See Samb, 1972: pp. 213-41. 
Outside of their creative works, the staunch belief in Islam and its Africaness on the part of Kane and Sow-Fall is equally unequivocal. Vincent Monteil (1964) quotes Kane, whom Wole Soyinka labels as "a diligent expositor of the Faith" [Soyinka, 1976: p. 81], arguing that

"If Islam is not the only religion of West Africa, it is its most important. I mean also that it seems to me that it is the religion of its heart."

In the same vein, Aminata Sow-Fall, one of the rising female literary figures in Africa today also expresses her faith in Islam and its place in contemporary Senegal. In response to an invitation to react to the controversial feminist anthology of her compatriote, Awa Thiam (1978), she offers the following guidelines for any liberation action, feminist or otherwise:

“...We wish that ... the woman liberates herself ... not through slogans, but in dignity and respect for our personality and ... religion, Islam which has never enslaved the woman."

This worldview permeates their creative works.

Less didactic and a bit more secularly-oriented than the poetry of the Wolof Muslim poets, the novels of Kane and Sow-Fall embrace Islam with equal enthusiasm and faith as the most effective antidote to Western Christian colonial culture of the Senegalese experience.

Such a view is projected symbolically in L'Aventure Ambigue in the form of a structure of polar opposites which, when juxtaposed in conflict, reveals the superiority of one over the other. Diallobe Islamic mysticism is contrasted and brought into conflict with Western materialist individualism, and this drama which is played out in the person and experience of Samba Diallo results in death. But this death is a far cry from the defeat of Diallobe Islamic doctrine. Instead, it represents a vindication of the Islamic doctrine of the ephemerality of mortal existence and the primacy of the spiritual. Soyinka's assessment of Kane's novel reinforces this point when he observes that in L'Aventure Ambique,

The victor is not traditional Diallobe society, nor the West which was responsible for the weakening of Diallo's spiritual roots, but the doctrine of death; the Teacher: the Word of Islam (p. 85).

In Kane's novel, the interest is not so much on a reconstruction of the process of the penetration of all external forces, both Arab-Islamic and Euro-Christian, into Senegal, as is the case with Ousmane Sembene's Ceddo, than on a reconstruction of the genesis and process of disintegration of an already established Islamic society. In other words, Kane's historical account of culture contact and conflict is aborted at the point of the Western incursion into Senegal, and it does not go back any 
further to consider the process by which Diallobe society came to acquire its Islamic character. For him, Islam is Diallobe and Diallobe is Islam. Hence the portrayal of the West and its materialist and individualist credo as the antithesis of Diallobe spiritualism and communalism. This dialectic accounts also for the philosophic intensity of Kane's fiction which, in its own way, becomes one of the most glowing panegyric to Islam by a contemporary Senegalese novelist in French. His glorified account of the mystic purity and commitment of the teacher of the text and of the principles and process of Islamic-Qur'anic education stands out in sharp contrast to the more critical account of the same process offered by Mahama Traore in Njangaan and Samb in Matraque Par Le Destin Ou La Vie D'Un Taalibe. L'Aventure Ambigue does not allow even the slightest touch of irreverence toward Islam. This is also a feature of Aminata Sow-Fall's La Grève des Battu.

Inspite of its lack of the philosophic and mystical aura of L'Aventure Ambigue and inspite of its more pronounced secular orientation, $L a$ Greve des Battú constitutes a significant part of that body of Senegalese creative works that come across as defenders of Islam. While the sphere of scrutiny in Kane's work is wide and almost epic in scope, La Greve des Battu limits itself to a fictional exploration of one of the five pillarprinciples of Islam, zakat, at work in real life. In this novel, irony and outright denunciation of the distortion of this principle by individuals become the devices used by Aminata Sow-Fall to underscore the importance of respect for the true ideals of zakat if individual and society are to attain fulfillment in Senegal.

La Greve des Battù is the story of Mour Ndiaye, Director of Public Health, whose efficient (officially) yet inhumane removal of beggars, the traditional recipients of alms and sacrifices, from the city in the interest of tourism thwarts his hopes of being appointed to the newly-created post of Vice-President of the country. The novel also details the disarray of individuals like Mour Ndiaye who see the beggar's strike (that is, their refusal to accept alms in the city) as the bane of their selfish objectives.

In exploring the divergence between the principle and practice of zakat in Senegal, Aminata Sow-Fall strongly indicts the society's obsession with the material which fosters a psychology of dependence easily exploited by charlatans masquerading as devout venerable marabouts. Deviation from the true altruism of zakat bastardizes its moral and philosophic intent, leading one of the beggars to lucidly observe that people no longer give out of the goodness of their heart but out of an instinct of self-preservation and improvement:

... it's not because of our rags, nor our physical disabilities, nor for the pleasure of performing a disinterested good deed that people deign to throw us the money we get as donations. First of all they have whispered their dearest and most secret desires to the alms they tender ... And when they are kind 
enough to invite you to share their steaming, odourous calabashes of millet porridge and curdled milk, do you imagine it's because they thought you might be hungry? No, my friends, that's the least of their worries. Our hunger doesn't worry them. They need to give in order to survive... They don't give for our sake; they give for their own sake [Translation by Blair, 1981, pp. 37-38].

This account of the distortion of zakat is contrasted with that of the real essence of zakat. Significantly, Sow-Fall entrusts the exposition of the latter to the mouth of Serigne Birama, Mour's main marabout, who functions in the novel as the principal watch-dog of true Islam. He spells out the nature of zakat thus:
... It is always good to make a sacrifice. It is a way of thanking the Creator who has entrusted to you what you offer to the poor to help them support their misery. It is good every time you can, you must give. Fortune has no fixed domicile; God has not bestowed it for all time. He has only offered it on loan. One must never cease to remember that [Translation by Blair, $\mathrm{p}$. $65]$.

The consistency with which Serigne Birama imparts this ideal of altruism throughout the novel reinforces Sow-Fall's preoccupation with the social, political and moral implications of the distortion of zakat for her society. She is quite aware of the all-embracing hold that Islam has on this society, and, like Kane, her interest lies not in challenging this religious domination, but in reaffirming its legitimacy and potential by thoroughly indicting its profit-minded detractors. In La Greve des Battu, these exploiters of Islam are to be found in all segments of the society, even though the spotlight is on Mour Ndiaye, a representative of the bourgeoisie. Sow-Fall's criticism does not in any explicit way focus on the Serigne-Marabout. Her concern is with the hypocritical attitude of the monied Westernized elite, in particular, toward the SerigneMarabout, revered and vilified, according to their needs. Like in L'Aventure Ambique, there is no room for religious irreverence and deviation in La Greve des Battu. These spell death, but of the kind that reaffirms the principles and ideals of Islam. The death of Mour Ndiaye's Vice-Presidential ambitions strips him off the beam blurring a true spiritual and moral vision of life. Only at this point is he able to begin to think clearly about the real meaning of his obligations and responsibilities as a public official and a devout Muslim, especially in his dealings with the less fortunate such as the beggars.

\section{THE IRREVERENTS}

If the Wolof Muslim clerics, Cheikh Hamidou Kane and Aminata Sow-Fall present religion and religious figures wrapped in an aura of 
mysticism and deep reverence, popular oral traditions strip them of these to poke fun at them without questioning either their legitimacy or power. The surface irreverence of the oral traditions vis-a-vis the Serigne-Marabout is but a thin veil for their deep faith in and allegiance to Islam. Parallels can be drawn here with other creative traditions such as Afro-American oral traditions which are rich in satirical narratives revolving around the foibles and shortcomings of respected religious figures, especially the preacher. And this inspite of a profound belief in Christianity.

Wolof satirical narratives about the Serigne-Marabout temporarily rob this sacred figure off certain trappings of sanctity, reduces him to the level of an ordinary mortal person, and thus laugh at his weakness as well as his strength. Among the more frequently-encountered images are those of the lecherous Serigne unable, in the midst of prayer, meditation or reading from the Holy Qur'an, to resist the sexual teasing of a young woman (Copans et Couty, 1976: pp. 103-4); the greedy and dishonest Serigne who falls victim to these moral deficiencies (Equilbecq, 1915: pp. 252-6); the Serigne who becomes the butt of the practical jokes and tricks of his taalibe who finally ditches him into a well (Copans et Couty, pp. 177-8); the Serigne who journeys to visit his disciples in another country, but who nearly starves to death on account of miscommunication due to language differences (Diop, B., 1961; pp. 137-40); the charlatan Serigne Fall who takes undue advantage of the faith and kindness of his host to freeload off him, but who gets kicked out of the house one evening because his host sees him eating biscuits after dinner (Diop, B., 1958: pp. 39-47)! the Serigne trickster who outwits a thief (Diop, B., 1963: pp. 208-15), a madman (Diop, B., 1963: pp. 114-22) and tricks a man into confessing that he repudiated his wife after arguing at first that he did not (Diop, B., 1961: pp. 21-30).

Also prominent in this tradition are stories spun around the adventures and pranks of the taalibe on his rounds of begging (Copans et Couty, pp. 102-3), and the "fast tongue" of that other human symbol of Islam, the naar (Moor), whose perceived inability to keep the smallest of secrets has inspired the popular labelling of a tattler among the Wolof as "a person who has a naar squatting in his/her stomach" (Diop, B., 1961: pp. 13-19).

The use of animal characters as metaphor for exploring human reality figures prominently in Wolof oral traditions as is the case with most other oral traditions. Thus, it is no surprise that certain animals become invested with Islamic religious attributes. Among the Wolof, the cat (called "muus" in Dakar and "woundou" in St. Louis) is believed to be Muslim, but this religiosity notwithstanding, he still remains a cat, selfish, artfully deceitful and greedy. The narrative, "Woundou ElHadji”, retold by Birago Diop(1963:pp. 123-30), effectively captures this duplicity to expose religious hypocrisy and the unscrupulous use of 
religion for selfish interests. A spoof of the $\mathrm{Hajj}^{7}$, especially the artificial glow of respectability and veneration it beams instantly on any returnee from Mecca, the narrative satirizes the El-Hadji who comes back from a pilgrimmage to the Holy Land only to revert back to his old evil selfish ways, aptly captured in Woundou's own argument that "La Mecque n'a jamais change personne" ("Mecca has never changed anyone") which he craftily uses to justify his inability to resist jumping on the succulent preys (the rats) in front of him.

Although the oral narratives mock these and other religious personalities, the Prophet Muhammad, the Islamic saints and the venerable leaders of the various Muslim sects in Senegal are sacrosanct, and, therefore, not the subject of any such narratives (see Copans et Couty, p. 36).

The influence of Islam on the formal properties of these narratives is minimal since they are basically pre-Islamic. What influence is there is to be discerned primarily in the area of lexical and idiomatic borrowings from Arabic. It is not uncommon to encounter oral narrative performers substituting "bissimilahi rahmaan...." for the traditional Wolof formulaic opening of narratives, "leboon" (there was a story). The Islamic background of the milieu is suggested through the use of Arabic words and allusions to the Qur'an and related religious matters. The ability of these pre-Islamic art forms to incorporate themes and styles from Islam is a testimony to their versatility and flexibility.

\section{THE ICONOCLASTS ${ }^{8}$}

Equally versatile and flexible, film offers the Senegalese artist yet another medium for creative engagement with his experience as well as that of his society, and the predominance of Islam in the latter has made religion a dominant thematic in his work. The film Njangaan by Mahama Traore provides a good example of such a work.

In spite of his professed belief in Islam, Traore uses this film to launch a severe attack on the Senegalese Serigne-Marabout in his role as the prime guardian of the first phase of Islamic education. However, like the other artists in the previous categories, his targets are the selfish detractors of Islam rather than Islam itself: "Je precise que je ne m'attaque pas à la religion en tant que telle mais a ceux qui la dètournent de ses objectifs pour opprimer le peuple en le trompant" (in Hennebelle et Ruelle, 1978: p. 140 ["I do not attack religion as such but I do attack those detract it from its objectives in order to oppress and do wrong to people."] As such, the film, whose title means taalibe or student, takes a jaundiced look at

${ }^{7}$ Cf. the highly sexually-oriented spoof of zakat in Copans et County, pp. 103-4. ${ }^{8}$ Because of space limitation and because of its close thematic kinship with Njangaan, Matraque Par Le Dstin On La Vie D'Un Taalibe will not be discussed here. 
the dara (the Qur'anic School) and its headmaster, the SerigneMarabout who is part of that group of people Traore labels as "les plus gros bourgeois du Senegal contemporain" (in Hennebelle et Ruelle, P. 140) ["the biggest bourgeois in contemporary Senegal"].

Set in the rural countryside against the background of a drought, Njangaan relates the tragic story of a six year old boy, Mame, who is sent away from his village to be educated at the famous dara of Serigne Moussa in Rip, just like his father was educated there by Serigne Moussa's father. But Mame ends up in Dakar as taalibe of Mahtar, Serigne Moussa's son, driven from the land by drought and hope of a better life in the city. On one of his begging rounds, Mame is hit and killed by a chauffeured driven Mercedes Benz.

Traore critically examines the system of education by ordeal common in the dara. Unlike Kane whose idealized portrait of the system in L'Aventure Ambigue radiates beauty, erudition and mysticism, Traore lays bare the crudeness, insensitivity and cruelty of a system whose abuse of the physical being of the taalibe far outweighs, in Traore's view, the potential mental and spiritual benefits to be gained from it. The principle of a healthy balance between intellectual pursuit and physical labor for a wholesome education embodied in the real system, is, in the case of Serigne Moussa, warped and manipulated, producing a disequilibrium in which the physical (because it produces immediate material benefits) becomes primary.

Thus, in Njangaan, begging no longer functions as a means of instilling a sense of humility in the taalibe. Instead, it is transformed into a meal and money-producing activity for the benefit of the Serigne and his family. In the dara, Mame and his fellow taalibe not only give up their food and money received from begging, but they are also required, under pain of severe flogging, to fill a daily quota. It is in one of his attempts to accomplish this task in the city that Mame loses his life.

Physical labor also combines with begging to further discredit the system in Traore's eyes. Ideally, because of its rural base, the dara aims to foster a sense of hard work and self-reliance by requiring the taalibe to do agricultural work. However, the application of this ideal has too often resulted in the taalibe serving as free labor to work long hours on the fields of the Serigne. Traore denounces this exploitation of child labor in the case of Serigne Moussa.

The complete control and freedom of action Serigne Moussa enjoys over the taalibe raises the issue of instructor and parental responsibility and obligation towards the child. Mame's father is portrayed as a victim (although a willing one) of his faith in Serigne Moussa. Unconcerned about the change in era, Mame's father's determination to continue tradition obliges him to deliver him to Serigne Moussa with instructions to mould him into a good Muslim or turn him into ashes. It is this unconditional transfer of parental authority in the name of religion to the Serigne that Traore questions in Njangaan, for such "abdication" 
absolves the Serigne of any responsibility whatsoever. The prevalence of excesses of physical abuse, malnutrition and dangers to which the taalibe are exposed are attributed partly to this mentality. Thus, Mame's father never questions the circumstances of his son's death. Serigne Moussa's religious rationalization of his demise is enough: Mame was made by Allah for a reason and placed in this world temporarily, and now that He needs him $\mathrm{He}$ has decided to take him back. Serigne Moussa then gingerly walks away with the gifts of expensive cloth just given to him by Mame's father securely tucked away under his arm. Traore challenges this view of life as interpreted by Serigne Moussa. This sets him apart from Kane who seems to glorify such a perspective in L'Aventure Ambigue.

Again, the divergence between true positive principle of Islam and its negative selfish practice and interpretation constitutes the focus of Njangaan, as it is also in Sow-Fall's novel and the narratives in the oral traditions. But Njangaan differs from these in its extremely irreverent presentation of the Serigne/Marabout as a child abuser and heartless exploiter of the religious faith and credulity of staunch believers. Traore himself offers the following assessment of Islam and the Serigne/Marabout in Senegal:

Islam had two roles in the days of colonialism: on the one hand, it was a bulwark against foreign penetration; on the other hand it was manipulated by the colonizer to his own benefit. France bought the marabouts to more effectively subdue the masses. On the surface, these marabouts were not (and are not) part of the industrial and commercial structures, they belonged only to the spiritual domains: but, in actuality, all the colonialist had to do was to issue them directives and they applied them. The situation has not changed substantially today, and maraboutism still plays the role of mystifier. Today's marabouts control a free labor force and have mechanisms for persuasion which are more effective than those of politicians who use radio and mass meetings. They are the biggest bourgeois in contemporary Senegal [in Hennebelle et Ruelle, p. 140].

Hence Traore's fundamental distrust of religious intermediaries of the type of Serigne Moussa, especially. Although Traore does not artistically explore the details and implications of this dual role of Islam and the Serigne/Marabout in any other work besides Njangaan, it is to the literary and cinematic oeuvre of his compatriot, Ousmane Sembene, that one has to turn to for the most consistent and radical examination of these issues. 


\section{THE APOSTATE}

The bulk of the work ${ }^{9}$ of Ousmane Sembene $(1960,1962,1963,1965$, $1968,1970,1971,1973,1977)$ reads like a dissertation on religion, Islam, in particular, and its impact on secular thought and action in Senegal. Like his predecessors and contemporaries in the first category of artists, Islam forms the dominant thematic in his work, but from a diametrically opposite perspective. And just as the narratives in the oral traditions and the film Njangaan focus on the distortion of certain principles of Islam by individuals such as the Serigne/Marabout, so too does the work of Sembene. But, unlike them, his work takes a radical step and goes much beyond the misdeeds of the individual to project and ultimately reject Islam itself as the obstacle to true totalization of individual and society in Senegal. The very first image of the very first film of Sembene, Borom Sarrett (1963), is a full shot of a mosque and, on the sound track, the voice of a muezzin issuing the call to prayer. The last image of the last film (to date) of Sembene, Ceddo (1977), is a woman blasting away the testicles of an Imam with a shotgun. In these two images, Sembene graphically and symbolically captures the hegemony of Islam in Senegal, on the one hand, and his own attitude towards it, on the other. The dialectic manifested by these two images, separated by a fourteen year time span, is the most persistent feature in the work of Sembene.

In Les Bouts de Bois de Dieu (God's Bits of Wood), the management of the railway is quiet cognizant of the power of the religious elite whose active help it seeks in its efforts to crush the workers' strike. Sembene contrasts the collaborationist tendencies of this elite with the defiance of the women who support the demands of the workers for a better deal. In Voltaique (Tribal Scars), many of the short stories in the collection also set up similar kinds of opposition in which Islam comes out on the side of oppression and, therefore, contested. This is the case in the story entitled "Communaute" (The Community) [pp. 117-21] which echoes a similar story referred to in our previous discussion of oral traditions. ${ }^{10} \mathrm{Here}$, the crafty Inekieve, the Chief Rat, sees through the religious smokescreen of the Imam, El-Hadji Niara, the Cat, and works out a contingency plan with his fellow traditional preys to thwart the real intentions of El-Hadji Niara and his tribe of cats. Another story, "Mahmoud Fall" (pp. 12738 ), details the punishment meted out to individuals who hide behind Arab-Islamic religious and secular symbols to extort money and material profit from believers. And in "Souleyeman" (pp. 139-56), a woman and elderly cynic team up to advocate a popular logic which makes a mockery of Islamic law regarding women, divorce and child custody.

\footnotetext{
Only Borom Sarrett and Ceddo will be discussed at length in this section. ${ }^{10}$ See pp. 11-12 of this essay.
} 
This dialectic also undergirds the very structure of Borom Sarrett which sets up an opposition between the cart-owner who relies inordinately on his "juju" and on the mercy of Allah and the "grands marabouts", on the one hand, and his wife who puts more faith in her own actions, on the other. Emitai repeats this opposition, but here the focus is on traditional religion instead of Islam. In Tauw, Sembene juxtaposes the image of the Qur'anic teacher (who sits back and sends his students out to beg or perform physical labor for money which they hand over to him) with the image of women busy at work in the market and of other men working or actively seeking work. The notion of "aate yalla" ("the will of Allah," in Wolof) which motors the worldview of the devoutly religious, such as Adja Awa Astou, and which favors the rich and the powerful in Xala, is contrasted with the realistic vision projected by the beggars and the physically-disabled who see the El-Hadji Abdou Kader Beyes of their society as the people mainly responsible for their socioeconomic conditions. Hence, their action against El-Hadji. In Ceddo, this dialectic is at its most extreme with the contending and conflicting ideologies of the Muslims and the ceddo brought into sharp focus. Here, Sembene commits the ultimate sacrilege when he sets up a woman as the prime challenger of the credo of Islam.

The artistic resolution of the conflicting opposites invariably projects the triumph of the material over the spiritual in different ways. A function of his declared atheism and Marxist orientation (see Hennebelle et Ruelle, p. 114 and 120), Sembene's rejection of Islam is firmly rooted in a materialist interpretation of the latter's impact on the worldview of the Senegalese individual and his/her approach and disposition toward real socio-economic problems of the kind confronting Senegalese society. A brief look at Borom Sarret and Ceddo will help outline the main contours of these issues.

The first fiction film by Sembene, Borom Sarrett, is a composite of the entire oeuvre of Sembne in that we find in this film the rudiments of the themes and styles that Sembene was to take up again and develop in subsequent full-length features. More specifically, Borom Sarrett offers the first succinct cinematic definition of Sembene's attitude towards Islam. Religion is here proven to be powerless in the face of practical problems of hunger, poverty and the law of the state which seems to be on the side of the educated and the rich. The cart-owner's incessant invocation of the mercy and protection of Allah and the "grands marabouts" fails to shield him or provide relief from his miserable condition, so that by the end of his day which the film documents, not only does he lose his only means of livelihood (the cart) when he is lured into a zone of the city forbidden to the likes of him and his tools of trade, but he is also stripped of his sense of manhood and self-esteem when forced to switch roles with his wife. And all this in spite of the loyal services of a 
horse named Al-Bourah. ${ }^{11}$ The assemblage of bones in the emaciated skeleton of the cart-owner's horse, which he significantly baptizes AlBourah, is at once a parody and irreverent negation of the splendor, the grace and the beauty of its more famous mythical namesake. Sembene resorts to such kinds of symbolism to ridicule aspects of Arab-Islamic belief and folklore held in reverence by Senegalese Muslims.

Borom Sarrett contrasts two different methods of dealing with socioeconomic challenges. The first one, represented by the cart-owner, is Allah and "grand marabout"-centric, while the other one, represented by his wife, places a premium on the concrete actions of human beings. The cart-owner's profound sense of religious piety is portrayed as a handicap which not only renders him vulnerable to exploitation, but also inhibits actions deemed imperative by Sembene for solving his most pressing problems. His decision to venture into the forbidden (to him and his "sarrett") "plateau" area of Dakar is a function of his naive belief in the power of his prayers to Allah and the "grands marabouts" to work miracles and keep the police away. Of course, these powers remain silent and impotent vis-a-vis the power of the Western-style police/state who confiscates his cart, and sends him back to the Medina, ${ }^{12}$ emasculated and accompanied by a hungry, malnourished, overworked and humiliated Al-Bourah. Should one see in this return to his familiar more wholesome neighborhood (as opposed to the decadence of the Westerninspired "plateau") a parody of the journey from Mecca to Jerusalem and then to the Dome of the Seven Heavens by the Prophet Muhammad?

By contrast, the cart-owner's wife's sense of determination and her promise to feed the family that evening are presented as more realistic and promising in terms of their efforts to satisfy their basic material needs. Although the film ends with the wife handing over the child to the husband and exiting the compound, thus letting the audience speculate as to what she would do to feed the family-(prostitution?)-, the important issue for Sembene is the potential for change implied in her action. She is the embodiment of Sembene's essential belief in man as the only force capable of solving practical problems of the kind faced by the society portrayed in the film.

The opposition between the spiritual and the material laid out in this first film becomes one of the basic building blocks of each of Sembene's subsequent works where the artist systematically undermines the reign of the religious which he links, in very clear terms, to secular systems of exploitation, while at the same time glorifying the virtues and promise of human-based and human-oriented action, individual as well as

\footnotetext{
${ }^{11} \mathrm{Al}$-Bourah (Wolof rendering of the Arabic Al-Buraq) is the winged horse (animal?) which carried the Prophet Muhammad first from Mecca to Jerusalem and then on His ascent to the Dome of the Seven Heavens.

${ }^{12}$ Medina is the name of the slum area of Dakar where the cart-owner and other people like him live.
} 
collective. This orientation is fleshed out in detail and from various perspectives in Mandabi, Tauw, Emitai and Xala. In these works, Sembene reinforces the Marxist notion of religion as opium of the people by realizing highly nuanced portraits of a society in the octopus grip of Allah, "grand marabouts", and traditional gods, a society held hostage by the Serigne-Marabout, real and charlatan, whose piety is, in Sembene's view, at once a mask for material gain and the reins holding back meaningful social progress. The genesis of this hegemony of Islam in Senegal is what Sembene attempts to spell out in his last film, Ceddo (1977), which has not yet received official clearance to show in Senegal for reasons that will hopefully become apparent in our discussion below.

Unlike the majority of his fellow Senegalese artists who subscribe to Islam's claim to indigenous antiquity in Senegal, Sembene presents Islam as one of the forces-(the other being Euro-Christianity)responsible for what Soyinka refers to as Africa's “enforced cultural and political exocentricity" (Soyinka, p. 99). Thoughts and practices hitherto taken as Senegalese or African by these artists and by the society at large are reexamined and shown to be of Arab-Islamic origin. Moreover, the process through which these Arab-Islamic thoughts and practices came to take root in Senegal is presented as insidious and violent, not in any way unlike the way Euro-Christian slavery, colonialism and imperialism made inroads into Senegal. Thus, for those artists who see culture conflict in Senegal only in terms of Africa (that is, Africa with Islam as indigenous) and the foreign West, Sembene offers in Ceddo an enlarged framework of conflict in which Arab-Islam and EuroChristianity are cast as foreign, intruding violently into an indigenous Africa with the aim of clearing and cultivating fertile ground to sow their own cultural and religious seeds. The foreign and, especially, the indigenous vehicles of this acculturation process are singled out as opportunists to be administered their own medicine of violence. Ceddo is, therefore, the most irreverent attack on Islam by a Senegalese artist. It reconstructs its history in Senegal from a diametrically opposite perspective from Kane's account in L'Aventure Ambigue, and the result is the shattering of the Islamic myth espoused and so eloquently conveyed in the work of the Wolof Muslim clerics, in particular.

The image of Islam portrayed in Ceddo is not a beautiful one at all. Muslims come across as scheming violent fanatics with little regard for the principles of self-determination and religious freedom. Their belief in the supremacy of Islam is translated into a series of highly studied moves which systematically eliminates the Christian Mission, the traditional secular power structure and a significant mass of the ceddo and their "pagan" beliefs. This plan culminates in the establishment of a rule based on principles of Islam with the Imam as head.

The design of the Imam on the society are quite clear from the very beginning. His initial litany of verbal attacks on the persistence of 
"paganism" among the ceddo is indirectly pointed at the Wolof secular authority, the King, now a convert, yet who tolerates the presence of such infidels in his society. These attacks become more pointed as the militancy of the Muslims intensifies and as the Imam's vow to undertake a jihad against all non-Muslims in the society looms closer to execution. To the King's question as to why the Imam never addresses him by the title King, the Imam replies that, for him, there is only one King, and that King is Allah. To the ceddo's complaint about the growing harassment from the Muslims and to their question as to whether religion is worth a man's life, the Imam, usurping the duty of the King, shouts blasphemy and renews his threats against them. This attitude captures the relationship of the Imam to the society around him, and it sets the stage for embarking on a crusade to bring about the rule of Allah. The Muslims burn down the Christian Mission and kill the white missionary, their principal rival for the soul of the ceddo. Next the news is announced that the King died the same night from a snake bite (a Muslim snake?), and the ceddo are then subdued and forcibly converted to Islam. Into this power vacuum steps in the Imam.

The Imam's accession to power marks the beginning of what Sembene conveys as one of the most radical processes of cultural transformation in Senegalese history. The Imam lays down new rules of spiritual and social conduct hitherto adhered to by only a minority, albeit a powerful one. Among the ceddo practices prohibited are consumption of alcohol, and the reproduction of human forms in art and weaving. The griot of the erstwhile royal court together with his fellow cronies are unceremoniously replaced by Qur'an-toting disciples of the Imam, and the regime of five daily prayers, the shahada (profession of faith) and Qur'anic education becomes mandatory. The high point of this process of change comes in the mass conversion sequence of the film where the ceddo have their heads shaved clean before undergoing a new baptism, receiving new Arabic-derived names such as Momadou, Sulayman, Baboucar and Ousmane. The music on the sound track of this particular sequence, Arthur Simms' "I'll Make It Someday," combines with the visuals to effectively echo similar experiences of Africans elsewhere in Africa and the Americas.

Historical reconstruction in Ceddo, then, aims to explode a deeply ingrained myth in Senegalese society. Sembene's own attitude toward this myth is most graphically defined in the final scene of the film when Princess Dior, heiress apparent to the throne of the now-dismantled secular kingdom, kills the Imam with a shotgun in full view of his disciples and new converts.

Ceddo may be unique in Senegalese artistic perceptions of Islam in terms of its tone, tenor and uncompromising view of the religion, but it is indicative of a growing current of thought in Afircan Literature and Film, in general. One is reminded of the equally caustic savaging of Islam in Yambo Ouologuem's Le Devoir de Violence (1968) /Bound to 
Violence], Ayi Kwei Armah's Two Thousand Seasons (1973) and, elsewhere, in Chancellor Williams' The Destruction of Black Civilization (1974).

His patent rejection of Islam notwithstanding, Sembene's work is saturated with Arabic terms, idioms and religious symbols which he skillfully integrates into the fabric of each work. Artistic conventions demand this, for he is representing a fictional milieu in which these predominate. One of the most common transition shots in many a Sembene film is the mosque, and passage of time is usually marked by reference to the five daily prayers. Like his colleagues, he makes creative use of lexical and idiomatic items culled from Arabic for characterization and quite often for satire and irony.

\section{CONCLUSION}

This brief survey has attempted to show the co-existence and interaction of multiple vehicles of artistic expression in Senegal, vehicles which serve to convey individual ideologically-oriented assessments of the impact of Islam in Senegal, a country with a population of approximately six million, ninety percent of which are Muslim. Vacillating between extremes of reverent apologia and uncompromising agnosticism, with reformist orientations in between, these assessments all convey the almost absolute hegemony of Islam in Senegal. Whether from the right, the middle or the left, the works of the artists examined here converge on at least two counts. First, they project the same overall image of Euro-Christianity and Western culture as villain-(for different reasons, of course)-vis-a-vis African and Senegalese culture. The same cannot be said for the Arab-Islamic image where there is a conspicuous absence of any such consensus. Secondly, these works are united by a common concern for the health and future direction of Senegal and the Senegalese individual. As such, they form a very important part of the efforts of Africans, in general, to come to terms with the myriad of forces that have historically shaped and influenced the character of contemporary Africa. 


\section{REFERENCES}

1. COPANS, J. et COUTY, P. (1976). Contes Wolof du Baol, Paris: Union Générale d'Editions.

2. BEHRMANN, Lucy. (1970). Muslim Brotherhoods and Politics in Senegal, Cambridge, Mass.: Harvard University Press.

3. CRUISE-O'BRIEN, D. (1971). The Mourides of Senegal: The Political and Ecomomic Organization of an Islamic Brotherhood, Oxford: Clarendon Press.

-. (1975). Saints and Politicians, Cambridge: Cambridge University Press.

4. DIA, M. (1975). Islam, Societés Africaines et Cultures Industrielles, Dakar: Nouvelles Editions Africaines.

5. DIOP, Bamba, M. (no date). Lat Dior et l'Islam suivi de La Doctrine Sociale de Mouhamadou Bamba, Bruxelles: Les Arts Graphiques.

6. DIOP, Birago. (1958). Les Nouveaux Contes d'Amadou Koumba, Paris: Présence Africaine.

-. (1961). Les Contes d'Amadou Koumba, Paris: Présence Africaine. (first published in 1948).

-. (1963). Contes et Lavanes, Paris: Présence Africaine.

7. EQUILBECQ, F.V. (1915). Essai sur la Littérature Merveilleuse des Noirs suivi de Contes Indigènes, Paris: Ernest Leroux.

8. HENNEBELLE, G. et RUELLE, C. (1978). "Les Cineastes d'Afrique Noire," Afrique Litteraire et Artistique, No. 49, Numero special.

9. JOHNSON, L. (1980). "Crescent and Consciousness: Islamic Orthodoxies and the West African Novel," Research In African Literatures, Vol. 11, No. 1, Spring, 26-49.

10. KA, Moussa. (1968). "Ma dyema burati...," Bulletin de l'IFAN, T.XXX, Ser. B, No. 3, 847-60. Transcrit et traduit en francais par Bassirou Cissé.

11. KANE, C. A. (1962). L'Aventure Ambigue, Paris: Julliard. Translated into English by Katherine Woods, 1969. Ambiguous Adventure, New York: Collier Books.

12. MONTEIL, V. (1964). L'Islam Noir, Paris: Seuil.

13. SAMB, Amar. (1968). "L'Influence de l'Islam sur la Litterature-'Wolof'," Bulletin de l'IFAN, T. XXX, Ser. B, No. 2, 628-41.

-. (1971). "Essai sur la Contribution du Senegal à la Litterature d'Expression Arabe," Bulletin de l'IFAN, T. XXXII, Ser. B, No. 3, 658-63.

-. (1972). Essai sur la Contribution du Sénegal a la Littérature d'Expression A rabe, Dakar: IFAN, Memoire No. 87.

-. (1973). Matraque Par Le Destin Ou La Vie d'Un Taalibe, Dakar: Nouvelles Editions Africaines.

14. SEMBENE, O. (1960). Les Bouts de Bois de Dieu, Paris: Le Livre Contemporain. (novel)

-. (1962). Voltaique, Paris: Présence Africaine (short stories). Translated into English, 1974. Tribal Scars, London: Heinemann.

-. (1963). Borom Sarrett (film). 
-. (1965). Vehi Ciosane ou Blanche Genese suivi du Mandat, Paris: Présence Africaine (two novelettes). Translated into English by Clive Wake, 1972. The MoneyOrder with White Genesis, London: Heinemann.

-. (1968). Mandabi (film).

-. (1970). Tauw (film).

-. (1971). Emitai (film).

-. (1973). Xala, Paris: Presence Africaine (novel-the film adaptation came out in 1974). Translated into English by Clive Wake, 1976. Xala, Westport, Conn.: Lawrence Hill \& Co.

-. (1977). Ceddo (film).

15. SOW-FALL, A. (1976). "Africa Donne la Parole aux Negresses," Africa, No. 111, mai, 53 .

-. (1979). La Gréve des Battu, Dakar: Nouvelles Editions Africaines. Translated into English by Dorothy Blair, 1981. The Beggars' Strike, London: Longman.

16. SOYINKA, W. (1976). Myth, Literature and the African World, Cambridge: Cambridge University Press.

17. THIAM, A. (1978). La Parole Aux Negresses, Paris: Denoel/Gonthier.

18. TRAORE, M. (1974). Njangaan (film). 